\title{
34. INTERSTITIAL WATER STUDIES, LEG 81
}

\author{
Joris M. Gieskes and Kirk Johnston, Scripps Institution of Oceanography ${ }^{2}$
}

\begin{abstract}
Interstitial water studies on samples obtained during Leg 81 have revealed substantial changes with depth in dissolved calcium, magnesium, strontium, potassium, and lithium. Calcium and magnesium concentration changes result from alteration reactions, primarily in the basalts and also in the volcanic sediments overlying the basalts. Similarly, depletions in potassium are the result of reactions in volcanic sections of the drill holes. Lithium has its main source in the volcanic sediments. On the other hand, strontium-concentration maxima occur at the ooze-chalk boundary and are the result of carbonate recrystallization reactions. Distinct correlations between calcium gradients and extents of concentration maxima in strontium with sedimentation rates suggest (1) build up of calcium concentrations below diffusion communication depth and (2) increased rates of recrystallization of carbonate with rate of sedimentation. The latter process is probably related to the more "corrosive" character of the sediments as the result of organic carbon diagenesis.
\end{abstract}

\section{INTRODUCTION}

During Leg 81 of the Deep Sea Drilling Project (DSDP), four sites were drilled in the vicinity of Sites 403 and 404 on the margins of the Rockall Plateau (Fig. 1). Our previous work (Ellis et al., 1979) at Sites 403406 of Leg 48 revealed large concentration gradients in calcium and magnesium, but unfortunately no deep penetrations to igneous basement rocks were accomplished. Similarly Manheim et al. (1972) established concentration gradients in calcium and magnesium at Site 116, whereas one data point level at Site $117(\sim 223 \mathrm{~m}$ subbottom) also revealed a large increase in calcium and a decrease in magnesium. Sites 552-555 of Leg 81 did reach volcanic basement rocks and thus represent a far more complete picture of the concentration gradients of interstitial water constituents.

In this chapter we present the data obtained both on D. V. Glomar Challenger and in our own laboratory on interstitial waters obtained during Leg 81 . Studies of the oxygen isotope composition of the waters and the strontium isotope composition of dissolved strontium are presently underway, and these studies will in the future serve to constrain the mechanisms of the reactions postulated in this chapter as the cause of observed concentration changes.

\section{METHODS AND RESULTS}

Shipboard analyses comprised determination of $\mathrm{pH}$, alkalinity, salinity, chloride, calcium, and magnesium. In our shore laboratory we determined values of strontium, lithium, potassium, sulfate, ammonia, and silica. Methods used have been described by Gieskes (1974), Gieskes and Lawrence (1976), and Gieskes et al. (1982).

All the data are tabulated in Table 1 and are graphically represented in Figures 2, 3, 4 and 5 (Sites 552, 553, 554, and 555).

\section{DISCUSSION}

Before presenting a general discussion of the data obtained in this study it appears appropriate to describe

\footnotetext{
${ }^{1}$ Roberts, D. G., Schnitker, D., et al., Init. Repts. DSDP, 81: Washington (U.S. Govt. Printing Office).

2 Address: Scripps Institution of Oceanography, La Jolla, CA 92093.
}

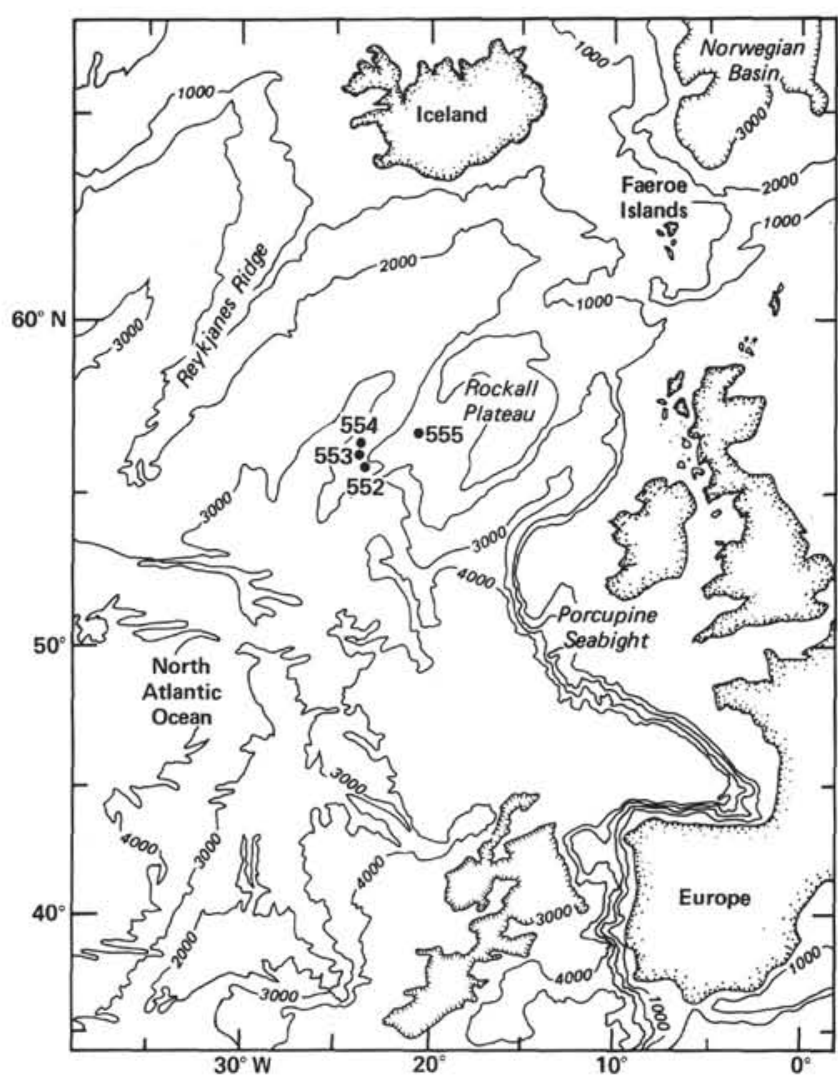

Figure 1. Map of Leg 81 sites.

the results of each individual site. Sedimentation rates over the last 50 m.y. are summarized in Figure 6.

\section{Site 552 (Fig. 2)}

The upper $173 \mathrm{~m}$ of the sediment column have been deposited at rates of $\sim 20 \mathrm{~m} / \mathrm{m}$.y. These sediments consist primarily of foram-nannofossil oozes, which turn into chalks at $\sim 142 \mathrm{~m}$ and deeper. Below $174.5 \mathrm{~m}$ depth volcanic contributions become increasingly important, with basalt occurring at $283 \mathrm{~m}$. 
Table 1. Interstitial water chemistry, Leg 81.

\begin{tabular}{|c|c|c|c|c|c|c|c|c|c|c|c|c|c|}
\hline $\begin{array}{c}\text { Sample } \\
\text { (interval in } \mathrm{cm} \text { ) }\end{array}$ & $\begin{array}{l}\text { Sub-bottom } \\
\text { depth (m) }\end{array}$ & $\mathrm{pH}$ & $\begin{array}{l}\text { Alk meq } \\
\left(\mathrm{dm}^{-3}\right)\end{array}$ & $\underset{(\mathrm{g} / \mathrm{kg})}{\mathrm{S}}$ & $\underset{(\mathrm{mM})}{\mathrm{Ca}}$ & $\underset{(\mathrm{mM})}{\mathrm{Mg}}$ & $\underset{(\mathrm{g} / \mathrm{kg})}{\mathrm{Cl}}$ & $\underset{(\mu \mathrm{m})}{\mathrm{Sr}}$ & $\underset{(\mu \mathrm{m})}{\mathrm{Li}}$ & $\underset{(\mathrm{mM})}{\mathrm{K}}$ & $\begin{array}{l}\mathrm{SO}_{4} \\
(\mathrm{mM})\end{array}$ & $\begin{array}{l}\mathrm{NH}_{4} \\
(\mu \mathrm{m})\end{array}$ & $\underset{(\mu \mathrm{m})}{\mathrm{Si}}$ \\
\hline \multicolumn{14}{|l|}{ Hole 552} \\
\hline $1-2,144-150$ & 3 & 7.41 & 2.82 & 36.8 & 11.1 & 52.7 & 19.51 & 115 & 31.3 & 10.6 & 26.8 & 0 & 354 \\
\hline $3-3,144-150$ & 113 & 7.22 & 3.22 & 36.0 & 16.2 & 48.3 & 19.63 & 460 & 47.1 & 10.0 & - & 0 & 889 \\
\hline $6-4,114-120$ & 141 & 7.21 & 3.11 & 36.0 & 17.7 & 46.6 & 19.61 & 460 & 52.3 & 9.9 & 24.9 & 0 & 788 \\
\hline $9-4,114-120$ & 170 & 7.29 & 2.55 & 36.0 & 18.1 & 47.8 & 19.34 & 426 & 67.6 & 9.0 & - & 0 & 889 \\
\hline $12-6,144-150$ & 203 & 7.44 & 1.87 & 36.0 & 19.5 & 47.2 & 19.51 & 382 & 67.1 & 9.0 & 25.3 & 0 & 743 \\
\hline $16-1,85-95$ & 232 & 7.86 & 1.09 & 36.3 & 29.6 & 46.3 & 19.40 & 236 & 66.6 & 8.5 & - & 0 & 583 \\
\hline $21-2,135-150$ & 282 & 7.17 & 0.64 & 36.6 & 33.0 & 44.3 & 19.73 & 194 & 71.4 & 7.1 & 24.4 & 0 & 346 \\
\hline \multicolumn{14}{|l|}{ Hole 552A } \\
\hline $6-3,144-150$ & 28 & 7.42 & 2.66 & 36.0 & 11.9 & 51.7 & 19.29 & 213 & 29.2 & 11.0 & 29.2 & 0 & 411 \\
\hline $12-3,144-150$ & 59 & 7.27 & 3.15 & 36.3 & 13.3 & 50.7 & 19.44 & 345 & 31.4 & 10.3 & 27.4 & 0 & 585 \\
\hline $18-3,144-150$ & 86 & 7.25 & 3.32 & 36.0 & 14.6 & 50.2 & 19.34 & 403 & 36.6 & 9.9 & 27.5 & 0 & 770 \\
\hline $24-2,144-150$ & 112 & 7.29 & 3.34 & 36.0 & 15.7 & 48.4 & 19.54 & 429 & 47.2 & 9.8 & 27.5 & 0 & 744 \\
\hline $30-2,144-150$ & 142 & 7.28 & 3.07 & 36.0 & 16.5 & 47.6 & 19.48 & 444 & 47.1 & 9.6 & 26.6 & 0 & 774 \\
\hline $38-3,144-150$ & 183 & 7.24 & 2.90 & 36.0 & 17.9 & 46.8 & 19.62 & 443 & 62.6 & 9.6 & 26.3 & 0 & 876 \\
\hline \multicolumn{14}{|l|}{ Hole 553} \\
\hline $1-5,144-150$ & 8 & 7.39 & 2.98 & 35.8 & 11.1 & 53.3 & 19.43 & 120 & 31.3 & 11.6 & 26.3 & 0 & 412 \\
\hline \multicolumn{14}{|l|}{ Hole 553A } \\
\hline $4-4,144-150$ & 186 & 7.07 & 2.78 & 36.3 & 22.9 & 41.5 & 19.78 & 620 & 70.9 & 8.8 & - & 130.3 & 911 \\
\hline $7-2,140-150$ & 211 & 7.09 & 2.59 & 36.3 & 24.2 & 41.1 & 19.73 & 564 & 72.8 & 7.8 & 23.7 & 124.8 & 962 \\
\hline $11-2,140-150$ & 249 & 7.59 & 1.47 & 36.3 & 26.3 & 39.6 & 19.82 & 488 & 82.2 & 6.9 & - & 113.1 & 714 \\
\hline $14-6,140-150$ & 284 & 7.85 & 0.69 & 35.2 & 30.4 & 36.7 & 19.65 & 402 & 76.5 & 6.68 & 25.7 & 127.5 & 147 \\
\hline $18-1,140-150$ & 314 & 7.95 & - & 36.3 & 34.7 & 32.7 & 19.97 & - & - & - & - & - & - \\
\hline $21-1,140-150$ & 343 & 7.87 & - & 35.8 & 37.2 & 31.6 & 19.68 & - & - & - & - & - & - \\
\hline $24-1,135-150$ & 380 & 8.08 & 0.53 & 36.0 & 40.1 & 30.8 & 20.09 & 236 & 76.5 & 4.7 & - & 0 & 173 \\
\hline $27-4,140-150$ & 404 & 7.92 & 0.66 & 36.6 & 44.7 & 31.6 & 20.28 & 236 & 76.4 & 4.3 & 24.8 & 0 & 152 \\
\hline $37-5,140-150$ & 501 & 7.70 & 0.44 & 36.3 & 52.2 & 25.9 & 20.34 & 215 & 86.5 & 3.3 & - & 0 & 320 \\
\hline \multicolumn{14}{|l|}{ Hole 554} \\
\hline $1-4,144-150$ & 6 & 7.43 & 2.86 & 36.3 & 10.8 & 52.8 & 19.41 & 104 & 31.3 & 11.4 & 28.6 & 0 & 375 \\
\hline $5-6,144-150$ & 47 & 7.37 & 3.16 & 36.0 & 11.8 & 52.3 & 19.61 & 156 & 31.4 & 11.0 & 27.5 & 0 & 559 \\
\hline $7 \cdot 4,144-150$ & 63 & 7.37 & 2.86 & 36.3 & 11.9 & 52.0 & 19.65 & 180 & 20.9 & 10.9 & 27.4 & 0 & 735 \\
\hline \multicolumn{14}{|l|}{ Hole $554 \mathrm{~A}$} \\
\hline $3-1,144-150$ & 97 & 7.38 & 2.65 & 37,1 & 11.9 & 51.8 & 19.53 & 179 & 26.0 & 10.7 & 27.4 & 0 & 556.4 \\
\hline $6-2,140-150$ & 127 & 7.48 & - & 36.6 & 11.3 & 49.0 & 19.22 & - & - & - & - & - & - \\
\hline \multicolumn{14}{|l|}{ Hole 555} \\
\hline $2-3,144-150$ & 10 & 7.43 & 2.90 & 35.8 & 10.8 & 52.6 & 19.44 & 114 & 31.3 & 11.5 & 29.2 & 0 & 219 \\
\hline $5-5,144-150$ & 42 & 7.33 & 3.02 & 36.0 & 11.2 & 53.5 & 19.64 & 156 & 31.4 & 10.7 & - & 0 & 637 \\
\hline $8-5,144-150$ & 70 & 7.36 & 3.02 & 36.3 & 11.6 & 54.4 & 19.93 & 172 & 26.1 & 10.5 & 28.6 & 0 & 559 \\
\hline $9-2,144-150$ & 94 & 7.37 & 2.78 & 37.1 & 11.5 & 52.9 & 19.51 & 208 & 20.8 & 10.6 & - & 0 & 573 \\
\hline $11-2,144-150$ & 132 & 7.33 & 3.47 & 36.6 & 12.5 & 53.3 & 19.10 & 257 & 20.9 & 11.0 & 28.7 & 0 & 624 \\
\hline $15-1,144-150$ & 169 & 7.31 & 3.68 & 36.0 & 12.7 & 51.5 & 19.64 & 305 & 26.3 & 9.7 & - & 0 & 762 \\
\hline $19-2,144-150$ & 208 & 7.23 & 4.06 & 35.8 & 13.5 & 50.6 & 19.51 & 332 & 31.7 & 9.9 & 27.8 & 15.0 & 1018 \\
\hline $22-1,144-150$ & 235 & 7.29 & 3.59 & 35.8 & 13.5 & 50.6 & 19.51 & - & - & - & - & - & - \\
\hline $25-5,141-149$ & 270 & 7.25 & 3.91 & 37.1 & 14.7 & 52.6 & 20.45 & 321 & 36.9 & 8.2 & - & 0 & 579 \\
\hline $31-1,140-150$ & 321 & 8.05 & 1.24 & 35.5 & 17.3 & 46.0 & 19.36 & 258 & 66.7 & 7.3 & 25.4 & 0 & 61 \\
\hline $34-4,140-150$ & 354 & 7.48 & 1.25 & 35.5 & 18.7 & 46.0 & 19.53 & 251 & 97.5 & 7.0 & - & 87.4 & 20 \\
\hline $37-2,140-150$ & 379 & 7.44 & 1.51 & 35.2 & 21.7 & 43.0 & 19.64 & 246 & 107.9 & 5.9 & 25.9 & 143.1 & 20 \\
\hline $40-5,140-150$ & 412 & 7.28 & 0.73 & 35.2 & 24.5 & 39.6 & 19.34 & 250 & 112.5 & 5.7 & - & 128.0 & 61 \\
\hline $43-3,140-150$ & 438 & 7.61 & 0.88 & 35.2 & 25.0 & 40.7 & 19.12 & 230 & 117.8 & 5.0 & 25.4 & 20.5 & 179 \\
\hline $46-5,140-150$ & 469 & 7.47 & 1.41 & 36.3 & 26.1 & 41.7 & 19.48 & 210 & 107.9 & 5.0 & - & 0 & 195 \\
\hline $48-4,96-106$ & 486 & 7.43 & 0.98 & 36.3 & 26.4 & 45.0 & 19.90 & 209 & 102.4 & 4.7 & 26.9 & 0 & 20 \\
\hline $52-1,140-150$ & 520 & 7.39 & 1.19 & 36.6 & 26.0 & 46.1 & 19.93 & 184 & 97.5 & 4.8 & - & 0 & 20 \\
\hline $55-1,140-150$ & 549 & 7.53 & - & 35.5 & 32.7 & 37.4 & 19.14 & - & - & - & - & - & - \\
\hline $58-3,140-150$ & 580 & 7.41 & - & 35.5 & 41.3 & 29.8 & 19.56 & - & - & - & - & - & - \\
\hline $61-3,140-150$ & 609 & 7.73 & 0.57 & 35.5 & 47,3 & 25.8 & 19.32 & 257 & 153.0 & 3.4 & 22.2 & 15.1 & 15 \\
\hline $67-4,140-150$ & 666 & 7.29 & - & 36.3 & 62.7 & 20.6 & 19.59 & $\overline{1}$ & - & - & - & - & $\overline{\bar{n}}$ \\
\hline $88-4,140-150$ & 867 & 7.93 & 0.22 & 36.6 & 109.1 & 1.2 & 19.14 & 322 & 125.0 & 2.6 & 22.0 & 98.6 & 20 \\
\hline $92-3,0-10$ & 902 & 8.08 & - & 38.5 & 128.3 & 0.2 & 20.00 & - & - & - & - & - & - \\
\hline
\end{tabular}

Note: Dash equals no data.

Sedimentation rates of $\sim 20 \mathrm{~m} / \mathrm{m}$.y. usually are associated with only minor decreases in dissolved sulfate as a result of sulfate reduction processes (cf., Table 1).

Concentration gradients in dissolved calcium and magnesium are linear in the upper $200 \mathrm{~m}$, below which a relatively rapid increase in dissolved calcium occurs. Apparently the main sink for magnesium occurs in the underlying basalts, whereas dissolved calcium is also produced in the lower $\sim 100 \mathrm{~m}$ of volcanic sediments.

Dissolved strontium shows a clear maximum at $\sim 150$ $m$, i.e., close to the boundary of the ooze-to-chalk transition zone. Clearly this strontium is released by calcium carbonate shells during the carbonate recrystallization process (Baker et al., 1982). In the lower-lying volcanic sediments strontium concentrations are much lower, presumably as a result of uptake in the alteration products of volcanic matter.

Potassium has its principal sink in the underlying sediments and/or basalt.

Lithium concentrations increase rapidly below $\sim 150$ $\mathrm{m}$, i.e., in the siliceous-volcanic zone. We believe that the source of this lithium is the alteration of volcanic matter or of biogenic silica (see also Gieskes, 1981).

Dissolved silica concentrations reflect the presence of biogenic silica in the upper $200 \mathrm{~m}$, the lower sediment column shows lower concentrations, mostly as a result 

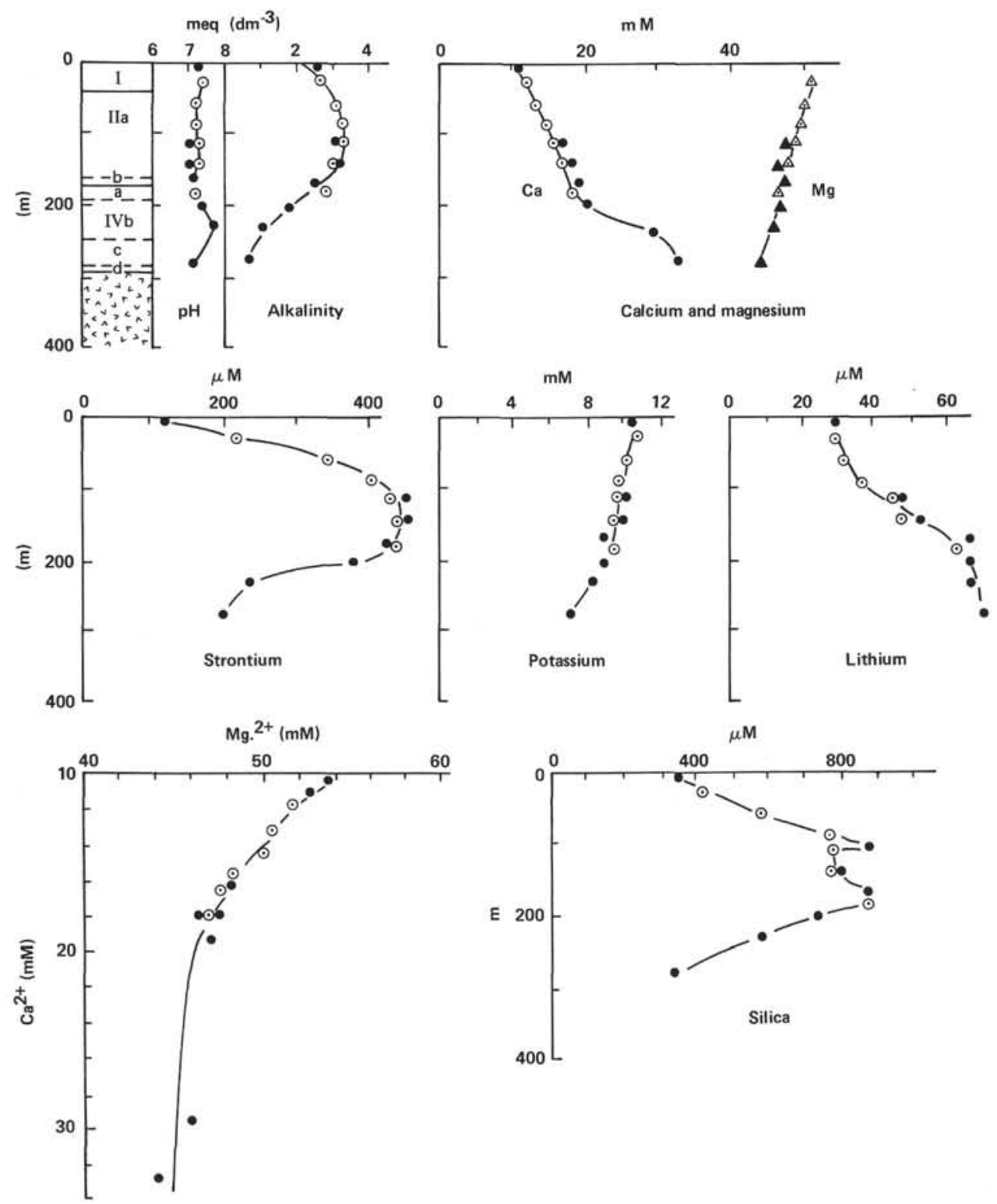

Figure 2. Interstitial water chemistry, Site 552. Lithologic Unit I. Foram-nanno ooze. Subunit IIa. Foramnanno ooze, biogenic silica; chalk increases below $142 \mathrm{~m}$. Subunit IIb. Nanno-foram chalk. Unit III. Foram-nanno chalk with Mn-nodules at base. Subunit IVa. Nannochalk-tuffs-chert at base. Subunit IVb. Calcareous-biosiliceous volcanic ash; tuffs. Subunit IVc. Nannochalk, marlstones, chert. Subunit IVd. Ferruginous diatom claystone. (Open symbols $=$ Hole $552 \mathrm{~A}$; closed symbols $=$ Hole 552 ).

of the transformation of biogenic silica to siliceous mudstones and cherts.

\section{Site 553 (Fig. 3)}

Interstitial water data obtained at this site show strong similarities to those obtained at Site 552. Concentration gradients are more pronounced for all components, especially dissolved calcium, magnesium, strontium, and potassium. The most logical explanation for this phenomenon is that Pleistocene-Pliocene sedimentation rates at Site 553 have been higher at this site than at Site 552. Estimated accumulation rates in the upper $217 \mathrm{~m}$ are $25-26 \mathrm{~m} / \mathrm{m}$.y., compared to $\sim 20 \mathrm{~m} / \mathrm{m}$.y. at Site 252.
Dissolved calcium has its principal source in the underlying basalts. Dissolved magnesium does show concentration depth variations that suggest uptake in the volcanic sediments as well as in the underlying basalts.

Dissolved lithium has its principal source in the volcanic section, whereas dissolved potassium shows a large concentration decrease and seems to have a sink both in the volcanic sediments and in the underlying basalts.

\section{Site 554 (Fig. 4)}

This site has been characterized by very slow sedimentation rates since the Pleistocene (during which rates were $20-30 \mathrm{~m} / \mathrm{m} . \mathrm{y}$.). The chalk transition is at $95 \mathrm{~m}$ and 

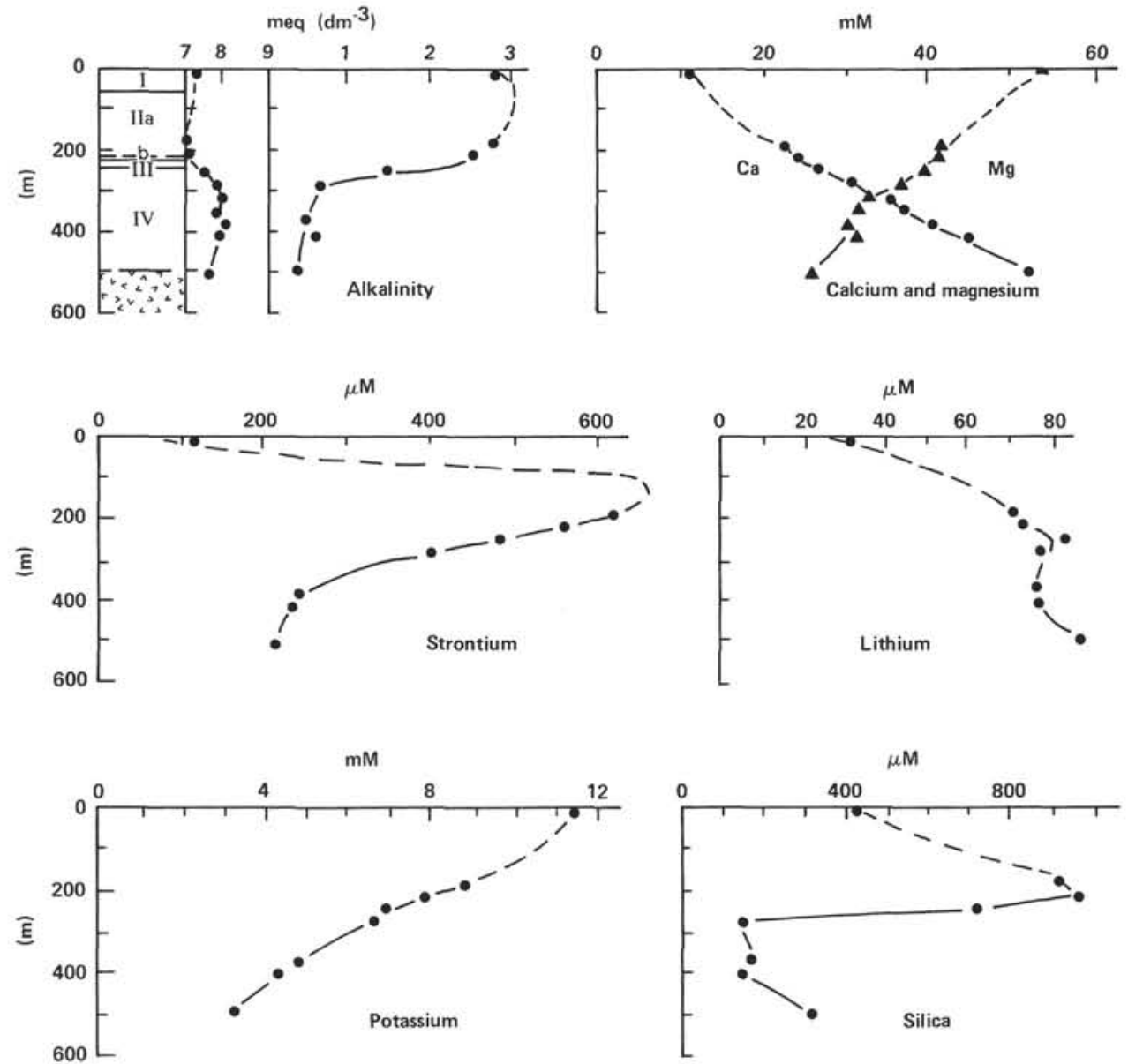

Figure 3. Interstitial water chemistry, Site 553. Lithologic Unit I. Unknown. Subunit IIa. Nanno ooze and foram-nanno ooze. Subunit IIb. Foram chalk. III. Nanno-foram chalk with Mn-nodules at base. Unit IV. Volcanic sediments and tuffs.

tuffaceous marlstones occur below a depth of $119 \mathrm{~m}$ and grade into basalt flows at $127 \mathrm{~m}$.

The general characteristic of this site is the virtual absence of significant concentration gradients. The decrease in magnesium at the base of the sediment column may well be in error. The maximum in strontium is much less pronounced than at Sites 552 and 553, but still indicates that active recrystallization occurs at the ooze-chalk boundary $(\sim 95 \mathrm{~m})$. We will later consider the problem of the near absence of concentration gradients at this site in greater detail.

\section{Site 555 (Fig. 5)}

Site 555 has been characterized by relatively slow sedimentation rates during the last $\sim 15$ m.y. (about $16-18 \mathrm{~m} / \mathrm{m} . y$. , cf. Fig. 6).

Changes in calcium and magnesium in the upper $300 \mathrm{~m}$ are very small-that is, in Units I and II, which consist mostly of calcareous oozes and chalks. The ooze/chalk transition occurs at $\sim 250 \mathrm{~m}$, at which depth once again a maximum in dissolved strontium is observed.

Below $300 \mathrm{~m}$ concentration gradients increase, roughly at the level where the first distinct decreases in porosity are observed. Especially between 350 and 420 m very low porosities characterize the sediments. At reduced porosities, changes in gradients are typically expected
(McDuff, 1978). A sink for magnesium must be located at $\sim 400 \mathrm{~m}$, probably associated with the silicification processes occurring in these layers. Below $520 \mathrm{~m}$, concentration changes with depth become large and appear to continue through the section characterized by volcaniclastic sediments and lava flows between 670 and 820 $\mathrm{m}$. We believe that to a large extent changes in dissolved calcium and magnesium result from exchange with underlying basalts, much in the manner proposed by McDuff (1981) and Lawrence and Gieskes (1981). Changes within the sediment column are due to less important reactions involving alteration of volcanic matter in the sediment column (Gieskes and Lawrence, 1981).

Changes in dissolved potassium indicate sinks in the volcanic sediments as well as in the underlying basalts.

Lithium concentrations support production of lithium in the volcanic sediments as at Sites 552 and 553.

\section{GENERAL DISCUSSION}

At all four sites of Leg 81, concentration gradients in dissolved calcium, magnesium, strontium, and potassium have been observed. Concentration gradients of calcium and magnesium appear to be determined mainly by exchange between the volcanic sediments and basaltic basement and the overlying sediments. The concentration depth profile of strontium on the other hand is 

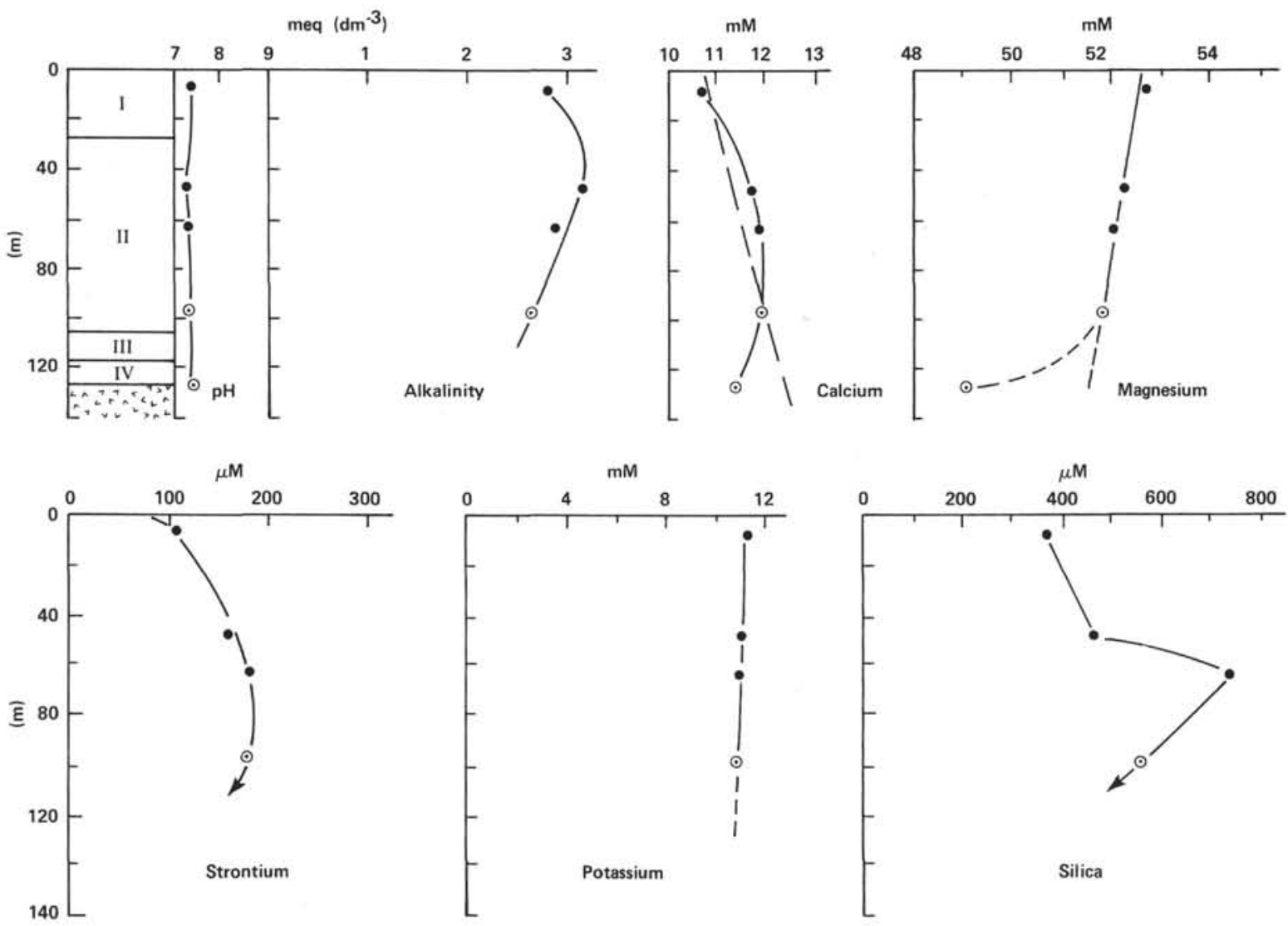

Figure 4. Interstitial water chemistry, Site 554. Lithologic Unit I. Foram oozes and marls. Unit II. Foram-nanno oozes; chalk at base. Unit III. Chalks-Mn nodules at base. Unit IV. Tuffaceous marlstones and tuffs. (Open symbols = Hole 554A; closed symbols $=$ Hole 554).

largely a function of carbonate recrystallization processes, the maximum usually occurring at the depth of the ooze-chalk transition. These observations are in general agreement with previous interpretations of such concentration changes. McDuff (1981) and Gieskes and Lawrence (1981) have shown that alteration reactions in basalts of Layer II and of volcanic matter dispersed in Layer I are the principal causes of the observed increases in dissolved calcium and decreases in magnesium. Mass balance calculations based on the oxygen isotope distribution in the interstitial waters have shown that the main cause of $\delta^{18} \mathrm{O}$ depletions (and calcium release) is alteration of basalts in Layer II, with a relatively minor contribution by volcanic matter dispersed in the sediments (Lawrence and Gieskes, 1981; Gieskes and Lawrence, 1981). The contributions by volcanic matter in the sediments have been shown to be related to rapid changes in the ${ }^{87} \mathrm{Sr} /{ }^{86} \mathrm{Sr}$ ratio of dissolved strontium (Hawkesworth and Elderfield, 1978; Elderfield and Gieskes, 1982; Gieskes et al., in press). Concentration changes in calcium and magnesium usually appear unrelated to those in dissolved strontium (Gieskes, 1983), mostly because dissolved strontium increases are principally the result of carbonate recrystallization reactions (Baker et al., 1982, Elderfield et al., 1982). Any small changes in magnesium associated with this latter process are expected to be minor (Matter et al., 1975), at best on the order of the strontium concentration changes, and hence would hardly be detectable on top of the much larger changes in dissolved magnesium as a result of reactions involving volcanic matter alteration.

The importance of the sites drilled during Leg 81 is in their closely spaced distribution and in the fact that they are characterized by similar sedimentation patterns but by dissimilar accumulation rates. Figure 6 shows a general diagram of sedimentation rates at Sites 552 to 555 . Dissimilarities are especially noticeable during the last 10-12 million years (Quaternary-middle Miocene). Average rates are as follows for this period: Site 552: $\sim 20$ $\mathrm{m} / \mathrm{m} . \mathrm{y}$., Site 553: $\sim 25 \mathrm{~m} / \mathrm{m}$.y., Site 554: $\sim 10 \mathrm{~m} / \mathrm{m} . \mathrm{y}$, and Site 555: $\sim 16-17 \mathrm{~m} / \mathrm{m} . \mathrm{y}$. For these reasons it appears appropriate to investigate the role of increased sedimentation rates on the nature of the concentration gradients. In the following discussion we assume an average diffusion coefficient for $\mathrm{Ca}^{2+}, \mathrm{Mg}^{2+}$, and $\mathrm{Sr}^{2+}$ of $\sim 2 \times 10^{-6} \mathrm{~cm}^{2} / \mathrm{s}$ (McDuff, 1981), and we will consider the "diffusion path length" $(\sqrt{2 \mathrm{Dt}})$ over the last $10 \mathrm{mil}-$ lion years, as well as the so called communication length ( $z=D / u$, where $u=$ sedimentation rate: Gieskes, 1975). In Table 2 data are presented on the sedimentation rates, the diffusion path length, communication length, and the depth of basaltic basement. Inspection of this table indicates that the diffusion path length is smaller than the depth of basement at Sites 553 and 555, and larger 

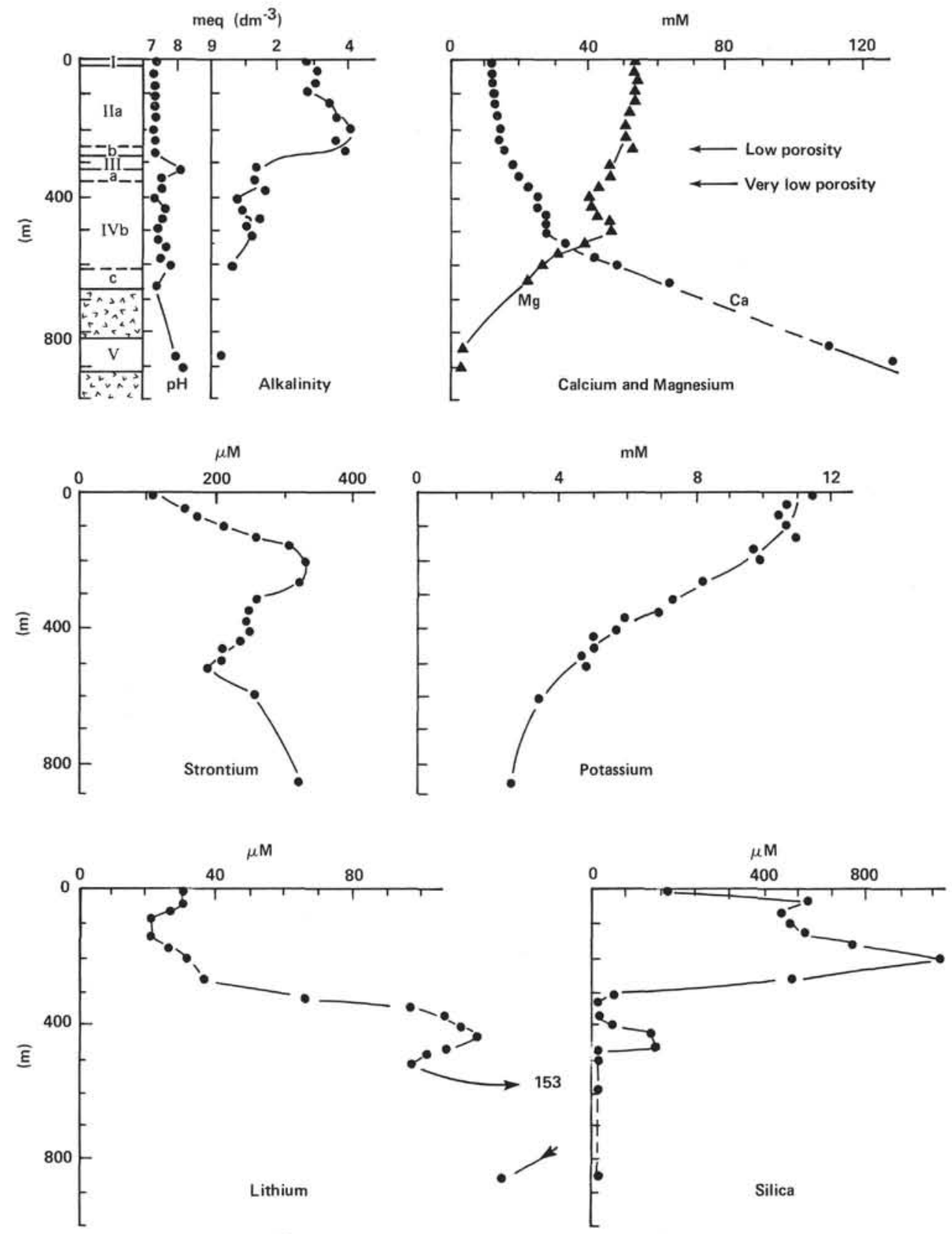

Figure 5. Interstitial water chemistry, Site 555. Lithologic Unit I. Cyclic calcareous muds and ooze. Subunit IIa. Foram-nanno ooze. Subunit IIb. Foram chalk and ooze. Unit III. Vitric tuff, chalk, and limestone. Subunit IVa. Zeolitic tuff and lapilli tuff. Subunit IVb. Carbonaceous mudstones, tuffs. Subunit IVc. Volcanic tuff, sandstones, and mudstones. Unit V. Volcanic tuffs, sandstones, and mudstones.

at Sites 552 and 554. Similarly the communication length at Site 552 is about equal to basement depth, smaller at Sites 553 and 555 , and only much larger at Site 554 .

Strontium concentration maxima correlate very well with sedimentation rates as can be seen from Figure 7. Typically, the ooze-chalk boundary at each site occurs at about the same age, i.e., $\sim 10$ million years. Calcium gradients are linear to depths well below these strontium maxima, and the slopes of the gradients correlate well with sedimentation rates (Figs. 7, 8).

Let us now consider the steady state diffusion equation (McDuff, 1978; Gieskes, 1983):

$$
0=\frac{\delta}{\delta z}\left(p D_{b} \frac{\delta c}{\delta z}\right)-p u \frac{\delta c}{\delta z}+R
$$

where $p=$ porosity; $D_{b}=$ bulk diffusion coefficient; $u$ $=$ pore water advective velocity relative to sediment-sea interface; $R=$ production of dissolved strontium (magnesium or calcium). If $u<25 \mathrm{~m} / \mathrm{m}$.y. and $D_{b}$ is constant at $\sim 2 \times 10^{-6} \mathrm{~cm}_{b}^{2} / \mathrm{s}$, then the diffusive term is the dominant transport term, and if $R=0$, linear concentration gradients should result. The production of strontium occurs well within the communication length, and thus any differences in the concentration depth profiles 


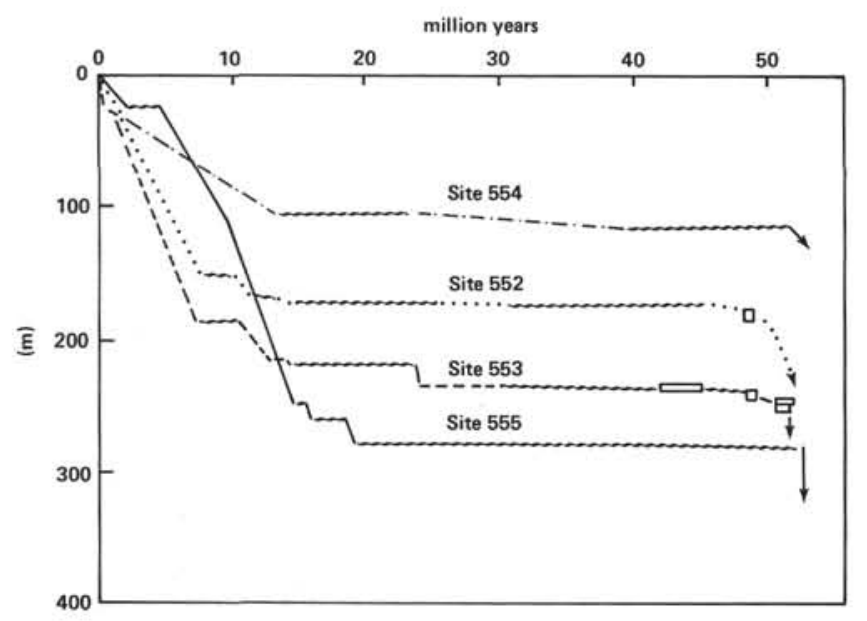

Figure 6. Sedimentation rate diagram for Sites 552-555.

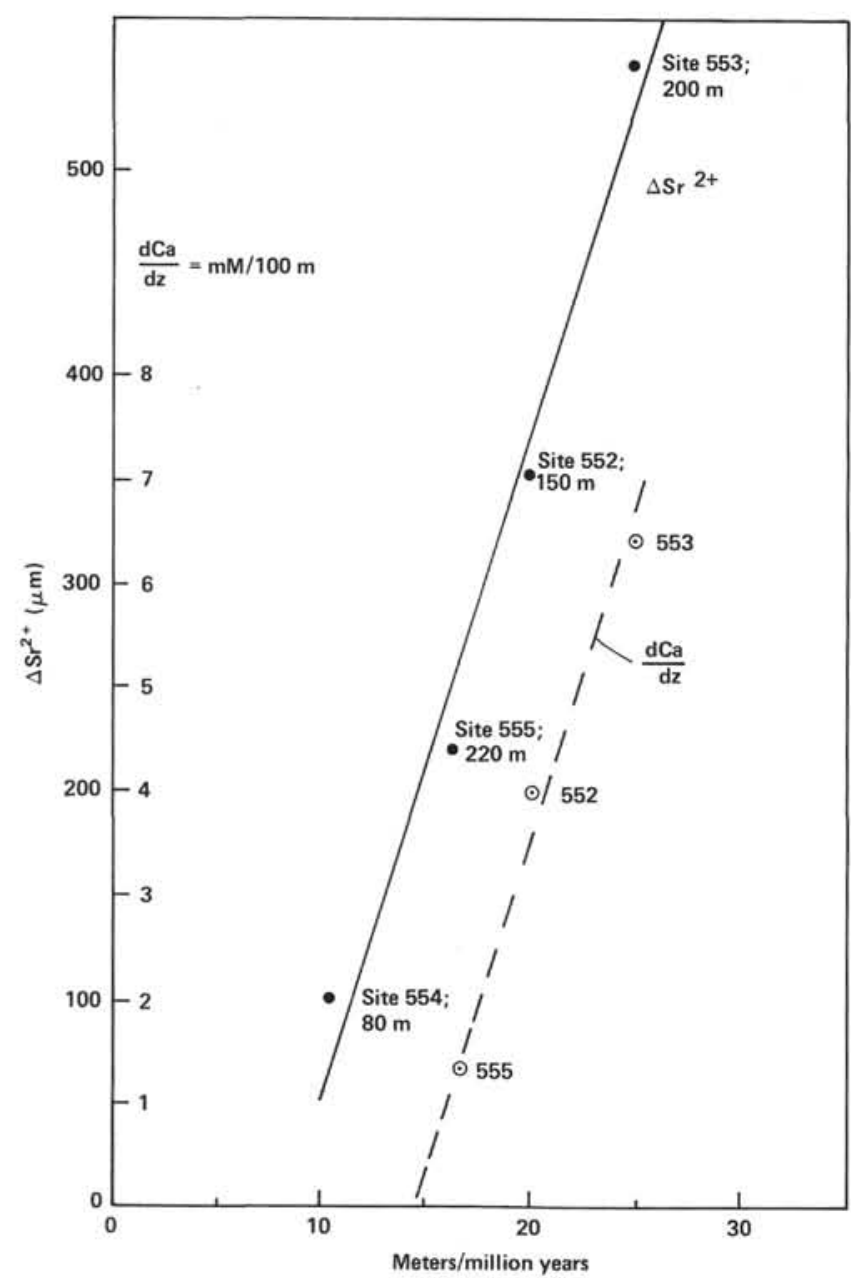

Figure 7. Concentration changes in $\mathrm{Sr}$ and gradients in $\mathrm{Ca}$ vs. recent sedimentation rates.

must be caused by the production term. Therefore, recrystallization rates are a function of sedimentation rate and are probably related to a more "corrosive" nature of the sediment, resulting for instance from increased
Table 2. Diffusion calculations, Sites 552, 553, 554, and 555, Leg 81.

\begin{tabular}{ccccc}
\hline & & $\begin{array}{c}\text { Path length } \\
\text { for diffusion, } \\
\sqrt{2} D t^{\mathrm{a}} \\
(\mathrm{m})\end{array}$ & $\begin{array}{c}\text { Communication } \\
\text { depth, } \\
D / u \\
(\mathrm{~m})\end{array}$ & $\begin{array}{c}\text { Depth of } \\
\text { basement } \\
(\mathrm{m})\end{array}$ \\
\hline 552 & 20 & 340 & 300 & 290 \\
553 & 25 & 340 & 240 & 500 \\
554 & 10 & 340 & 554 & 128 \\
555 & 17 & 340 & 353 & 670 \\
\hline
\end{tabular}

$\mathrm{a}_{t}=10 \mathrm{~m} . \mathrm{y}$. ago.

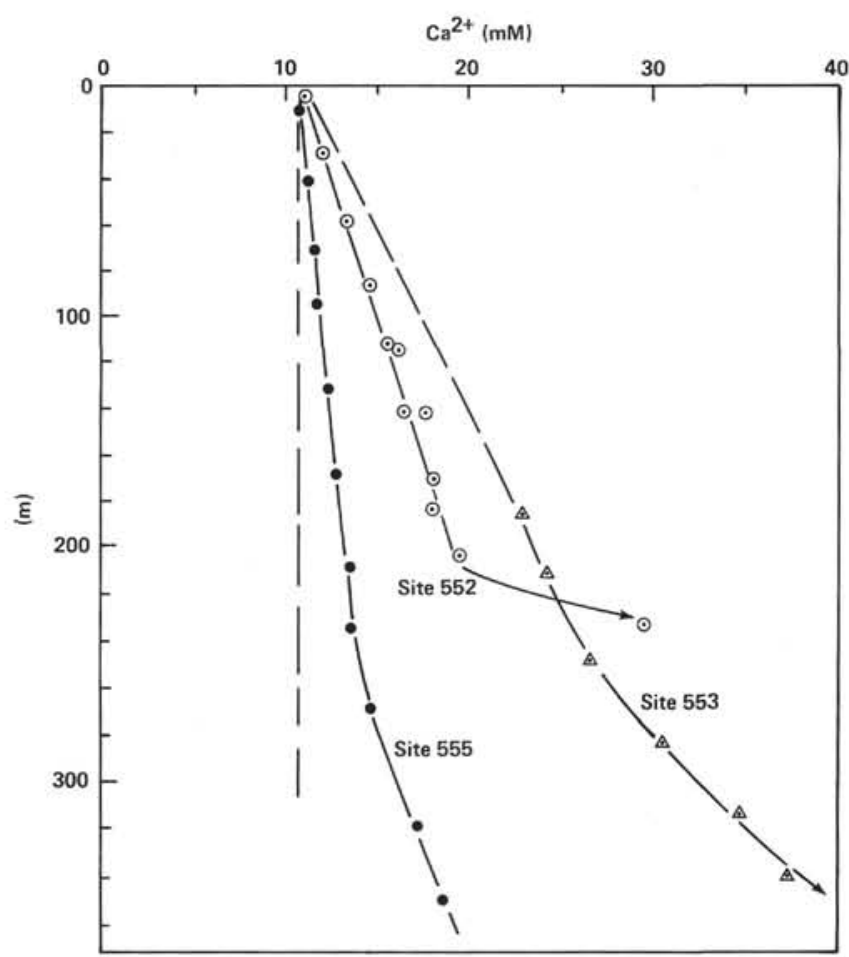

Figure 8. Concentration-depth gradients of calcium, Sites 552, 553, 555 .

production of $\mathrm{CO}_{2}$ or $\mathrm{HCO}_{3}^{-}$as a result of sulfate reduction. This was suggested previously by Sayles and Manheim (1975).

In the case of the calcium (and magnesium) gradient (Figs. 7 and 8) the main source (sink for magnesium) is located in the underlying basalts, i.e., at depths greater than the communication length. We argue that in this case the increased slope of the calcium gradient, which would imply an increased flux of dissolved calcium, is mainly the result of a buildup of calcium concentration at depths greater than the communication length. If diffusion from underlying basalts is sufficiently slow, then gradients will be small at low sedimentation rates, $\mathrm{cf}$. Site 554.

\section{CONCLUSIONS}

Concentration gradients in dissolved strontium at Sites 552-555 of Leg 81 have been shown to be related to the process of carbonate recrystallization. Rates of these re- 
crystallization processes increase with sedimentation rates, primarily as a result of increased "corrosiveness" of the sedimentary environment, presumably the result of increased amounts of reactive organic carbon.

Concentration changes in dissolved calcium (increases) and magnesium (decreases) are related to reactions taking place in underlying volcanic sediments and basalts. Increases in concentration gradients with sedimentation rate result primarily from the buildup of calcium (or removal of magnesium) below the so-called diffusive communication depth. Basement serves as the primary source of dissolved calcium and also as an important sink for magnesium and potassium.

Dissolved lithium is produced in the volcanic sediments overlying basement basalts.

\section{ACKNOWLEDGMENTS}

We thank Mr. Ken Thompson for his diligent work as the shipboard chemist. This research was funded by NSF Grant OCE-80-23966. We thank Drs. R. E. McDuff and F. L. Sayles for their review of the manuscript.

\section{REFERENCES}

Baker, P. A., Gieskes, J. M., and Elderfield, H. E., 1982. Diagenesis of carbonates in deep sea sediments-evidence from $\mathrm{Sr} / \mathrm{Cr}$ ratios and interstitial dissolved $\mathrm{Sr}^{2+}$ data. J. Sediment. Petrol., 52: 71-82.

Elderfield, H., and Gieskes, J. M., 1982. Sr-isotopes in interstitial waters of marine sediments from Deep Sea Drilling Project cores. Nature, 300:493-497.

Elderfield, H., Gieskes, J. M., Baker, P. A., Oldfield, R. K., Hawkesworth, C. J., and Miller, R., $1982 .{ }^{87} \mathrm{Sr} /{ }^{86} \mathrm{Sr}$ and ${ }^{18} \mathrm{O} /{ }^{16} \mathrm{O}$ ratios, interstitial water chemistry and diagenesis in deep-sea carbonate sediment of the Ontong-Java Plateau. Geochim. Cosmochim. Acta, 46:2259-2268.

Ellis, R., Pine, J., and Gieskes, J. M., 1979. Interstitial water studies, Leg 48. In Montadert, L., Roberts, D. G., et al., Init. Repts. DSDP, 48: Washington (U.S. Govt. Printing Office), 297-303.

Gieskes, J. M., 1974. Interstitial water studies, Leg 25. In Simpson, E., Schlich, R., et al., Init. Repts. DSDP, 25: Washington (U.S. Govt. Printing Office), 361-394.

1975. Chemistry of interstitial waters of marine sediments. Ann. Rev. Earth Planet. Sci., 3:433-453.

1981. Deep sea drilling interstitial water studies: Implications for chemical alteration of the oceanic crust, Layers I and II. SEPM Spec. Publ. 32:149-167.
1983. The chemistry of interstitial waters of deep sea sediments: Interpretation of Deep Sea Drilling data. In Riley, J. P., and Chester, R. (Eds.), Chemical Oceanography (Vol. 7): New York (Academic Press), 221-269.

Gieskes, J. M., Elderfield, H., Lawrence, J. R., Johnson, J., Meyers, B., and Campbell, A., 1982. Geochemistry of interstitial waters and sediments, Leg 64, Gulf of California. In Curray, J. R., Moore, D. G., et al., Init. Repts. DSDP, 64: Washington (U.S. Govt. Printing Office). 675-694.

Gieskes, J. M., Elderfield, H., Lawrence, J. R., and LaKind, J., in press. Interstitial water studies, Leg 78A. In Biju-Duval, B., Moore, J. C., et al., Init. Repts. DSDP, 78A: Washington (U.S. Govt. Printing Office).

Gieskes, J. M., and Lawrence, J. R. 1976. Interstitial water studies, Leg 35. In Hollister, C. D., Craddock, C., et al., Init. Repts. DSDP, 35: Washington (U.S. Govt. Printing Office), 407-424.

1981. Alteration of volcanic matter in deep sea sediments: Evidence from the chemical composition of interstitial waters from deep sea drilling cores. Geochim. Cosmochim. Acta, 45:1687-1703.

Hawkesworth, C. H., and Elderfield, H., 1978. The strontium isotope composition of interstitial waters from Sites 245 and 336, DSDP, Earth Planet. Sci. Lett., 40:423-432.

Lawrence, J. R., and Gieskes, J. M., 1981. Constraints on water transport and alteration in the oceanic crust from the isotopic composition of pore water. J. Geophys. Res., 86:7924-7934.

McDuff, R. E., 1978. Conservative behavior of calcium and magnesium in interstitial waters of marine sediments: Identification and interpretation. [Ph.D. dissect.]. University of California, San Diego.

1981. Major cation gradients in DSDP interstitial waters: The role of diffusive exchange between seawater and upper oceanic crust. Geochim. Cosmochim. Acta, 45:1705-1713.

Manheim, F. T., Sayles, F. L., and Waterman, L. S., 1972. Appendix I. Interstitial water studies on small core samples, DSDP, Leg 12. In Laughton, A. S., Berggren, W. A., et al., Init. Repts. DSDP, 12: Washington (U.S. Govt. Printing Office), 1193-1200.

Matter, A., Douglas, R. G., and Perch-Nielsen, K. 1975. Fossil preservation, geochemistry and diagenesis of pelagic carbonates from Shatsky Rise, Northwest Pacific. In Larson, R. L., Moberly, R., et al., Init. Repts. DSDP, 32: Washington (U.S. Govt. Printing Office), 891-921.

Sayles, F. L., and Manheim, F. T., 1975. Interstitial solutions and diagenesis in deeply buried marine sediments: Results of the Deep Sea Drilling Project. Geochim. Cosmochim. Acta, 39:103-127.

Date of Acceptance: September 16, 1983 